\title{
FAKTOR PENDORONG DAN PENGHAMBAT MODERNISASI \\ DESA PAKRAMAN
}

\section{GPB Suka Arjawa}

\author{
Program Studi Sosiologi, Fakultas Ilmu Sosial dan Ilmu Politik \\ Universitas Udayana \\ Email : suka_arjawa@yahoo.com
}

\begin{abstract}
ABSTRAK
Desa pakraman merupakan lembaga tradisionil di Bali yang mempunyai pengaruh mendalam di masyarakat. Desa pakraman dengan banjar parkaram yang ada di dalamnya, merupakan pusat dari jalannya ritual masyarakat Hindu. Akan tetapi, searah dengan perubahan sosial di Bali yang didorong oleh industri pariwisata, masyarakat mulai banyak mempertanyakan sikap rasional desa pakraman terhadap situasi sosial yang ada. Banyak anggota masyarakat yang merasa tersita waktu, tenaga dan biaya akibat berbagai aktifitas ritual sosial di desa. Penelitian ini bertujuan melihat langkah modernisasi yang terjadi di desa pakraman serta melihat faktor pendorong dan penghambat modernisasi tersebut. Penelitian dilakukan di Denpasar, Gianyar dan Tabanan karena tiga daerah ini merupakan wilayah yang paling besar terpengaruh laju pariwisata. Teori yang digunakan adalah teori-teori modernisasi, dengan metode penelitian eksploratif kualitatif. Temuan yang didapaatkan adalah sikap rasionalitas merupakan pendorong utama kemajuan-kemajuan yang terjadi pada desa pakraman. Sikap dan nilai-nilai tradisional merupakan penghambat utama modernisasi desa pakraman.
\end{abstract}

Kata Kunci: desa pakraman, modernisasi, rasionalitas.

\begin{abstract}
Desa Pakraman is the traditional organization ini Bali, which have deep influence in society. This desa, with banjar pakaraman as members, is the centre of the ritual in Balinese society. But, with the social change in Bali which bostered by tourism industry, many people have ask the desa pakraman role in social change. Many people had felt that they lost more of the time, energy and benefid caused by the many ritual in banjar. This research aimed to find how deep the modernization have adapted by desa pakraman, what the influence and what the obstacle they face to applied that modernization. This research hold ini Denpasar, Gianyar and Tabanan, becaused these regency are the most area which deep influenced by tourism industry. The modernization theory is applied in this research, with eksploratif-qualitatif method. The finding is that the rational pattern of society is the prime stimulus of modernization and the traditional pattern of society is the prime obstacle. Keyword: desa pakraman, modernization, rationality
\end{abstract}

\section{PENDAHULUAN}

Latar Belakang

Desa pakraman merupakan bentuk desa tradisionil masyarakat Hindu di Bali. Menurut Perda Provinsi Bali No 3 tahun 2001, desa pakraman adalah kesatuan masyarakat hukum adat di Provinsi Bali yang mempunyai satu kesatuan tradisi dan tata krama pergaulan hidup masyarakat umat Hindu secara turuntemurun dalam ikatan Khayangan Tiga atau Khayangan Desa yang mempunyai 
wilayah tertentu dan harta kekayaan sendiri serta berhak mengurus rumah tangganya sendiri. Lembaga ini ada di setiap daerah tingkat II di Bali dan sampai saat ini berjumlah 1488 (Windya, 2017). Dalam keberadaannnya, desa pakraman di Bali terdiri dari beberapa banjar pakraman. Bagi banjar pakraman yang telah mempunyai Khayangan Tiga, satu banjar pakraman yang membentuk satu desa pakraman.

Di Bali terdapat dua jenis desa. Disamping desa pakraman yang mengacu pada kesatuan tradisionil masyarakat, juga ada desa dinas yang mengacu kepada sistem pengorganisasisan masyarakat dengan struktur kelembagaan yang sifatnya nasional. Jumlah desa dinas atau keperbekelan dan kelurahan yang ada di Bali adalah 674 (Windya, 2017). Dua desa ini dapat hidup berdampingan di Bali.

Dalam masyarakat Hindu Bali, desa pakraman mempunyai peran sentral. Sebagai desa yang mengayomi tempat persembahyangan Khayangan Tiga, maka aktifitas desa pakraman sangat terkait dengan keagamaan dengan berbagai rutualnya. Tindak lanjut dan perkembangan desa pakraman ini sangat ditentukan oleh ritual tersebut. Dengan demikian kehidupan sosial dari masyarakat yang ada di desa pakraman tersebut sangat ditentukan oleh cara pandang, upacara, dan sikap terhadap ritual yang diselenggarakan pada Pura Khayangan Tiga. Karena desa pakraman itu melingkupi banjar pakraman, maka segala aktivitas keagamaan tersebut juga melingkupi banjar pakraman. Warren (1993) menyebutkan bahwa aktivitas sosial masyarakat Hindu Bali, justru berada di banjar pakraman. Karena itu, disamping terlibat di dalam ritual upacara di Khayangan Tiga, maka banjar pakraman juga akan terlibat dalam ritual yang dilakukan oleh masyarakat. Dalam kepercayaan Hindu Bali, masyarakat mengenal ritual yang disebut Panca Yadnya. Ritual inilah yang mempunyai banyak dimensi dan praktik sosial yang banyak menyita waktum, tenaga dan biaya ekonomi.

Karena demikian banyaknya ritual tersebut, aktivitas masyarakat sering terganggu. Hal ini yang menimbulkan banyak persoalan. Pada tingkat masyarakat, menimbulkan masalah dalam hubungan dengan pekerjaan. Banyak masyarakat Hindu Bali yang sering bolos atau meninggalkan pekerjaan kantornya. Pada tingkat seperti ini, sering terjadi kesalahpahaman antara masyarakat Hindu Bali dengan kantor tempat bekerja. Ada hotel yang tidak bersedia menerima karyawan yang mengandut agama Hindu, padahal sesuai dengan Undang-Undang No.13 Tahun 2003, tentang keketanga kerjaan, telah menyatakan tidak boleh ada diskriminasi dalam merekrut karyawan (Tribun Bali.com, 17 April 2018, Nusa Bali.com, 17 April 2018, Theeast.co.id 13 Juni 2018). Pada tingkat hubungan sosial di dalam lembaga desa dan banjar pakraman, masalah yang muncul adalah soal denda jika tidak ikut ngayah dan pada tingkat yang lebih besar adanya anggota masyarakat yang disepekang (dihukum dikeluarkan dari desa pakraman), atau dilarang mengubur anggota keluarganya di kuburan tempat desa pakraman tersebut (lihat disertasi Suka Arjawa, 2016).

Di tengah demikian pesatnya perubahan sosial di Bali, terutama dengan iklim kerja pariwisata yang mengadopsi sistem kerja global-internasional, maka perubahan cara pandang desa pakraman terhadap lingkungan domestiknya dipandang akan mampu menekan konflik yang muncul tersebut. Modernisasi 
terhadap lembaga desa pakraman dipandang akan mampu memberikan solusi terhadap permasalahn yang muncul.

Tidak banyak tulisan yang mengupas tentang modernisasi desa pakraman di Bali. Suka Arjawa (2015), menekankan kapada kelemahan lembaga ini yang sejarah pembentukan dari masing-masing desa tersebut, hanya berlatar pada masyarakat lokal setempat. Disamping itu bagi generasi baru, pemilihan ketua atau kelihan dari lembaga ini menjadi momok mengkhatairkan karena sifatnya yang masih tradisional.

Disinilah persoalan yang akan dihadapi desa pakraman di masa mendatang sehingga modernisasi atau pembaruan sangat perlu diperhatikan.

Gde Wiryawan dkk (2015), menyebutkan bahwa hukum adat Bali sedang berada dalam pertarungan antara sistem hukum nasional dengan hukum adat Bali sendiri. Revitalisasi hukum adat Bali akan mampu memberikan kekuatan pada masyarakat Bali akan mampu terwujud apabila para pemangku adat membuat aturan yang didasarkan pada kesepakatan warga dengan mempertimbangkan berbagai aspek.

Tidak ada aspek pembaruan di dalam awig-awig desa pakramaan yang dicantumkan dalam penelitian diatas. Penelitian ini akan mampu melengkapi tulisan diatas.

Sirta (2016), menyebutkan bahwa desa pakraman mempunyai potensi politik, ekonomi, budaya, sosial, adat dan agama yang mempunyai tujuan untuk mensejahterakan masyarakatnya. Prajuru desa dalam melaksanakan tugasnya didasarkan atas pedoman awig-awig.

Penelitian yang dilaksanakan penulis ini, justru memberikan pandangan yang lebih jelas tentang tingkat kesejahteraan masyarakat tersebut, apabila jenis modernisasi yang dilakukan telah diketahui dan dikembangkan.

Suka Arjawa (2017), mengutarakan bahwa nilai-nilai demokrasi terdapat dalam desa pakraman di Bali, terutama dalam pembuatan dan isi dari awig-awig yang ada.

Tulisan ini masih belum memuat aspek modernisasi yang lebih besar, seperti sikap rasional masyarakat dii dalam desa pakraman tersebut, sehingga penelitian ini akan mampu melengkapi tulisan tersebut.

Dalam konteks itulah penelitian ini berupaya mencari jawaban tentang sejauh mana modernisasi tersebut telah dilakukan desa pekraman, faktor apa saja yang mendorong adanya pembaruan tersebut. Kemudian, jika ada hambatan faktorfaktor apa saja yang menghambat dan bagaimana wujud hambatan pembaruan tersebut. Sebagai sebuah kesatuan sosial yang melingkupi masyarakat, bagaimana pengaruh kemajuan dan hambatan tersebut bagi kehidupan sosial.

Olivier Galland, dkk (2018), mengatakan bahwa moderrnisasi tersebut mengacu kepada prinsip-prinsip rasionalisasi, yang mana pada bidang ekonomi dapat berupa mengembangkan dan meluaskan produksi, pada bidang politik dapat berupa adopsi dari prinsip-prinsip demokrasi dan pada bidang budaya mengutamakan hidup hemat dan efisien. Mengutip Weber dan Scott, ia menyebutkan bahwa dalam hal modernisasi dan rasionalisasi ini juga berhubungan dengan penggunaan ilmu pengetahuan dan melakukan perhitungan untuk 
merencanakan sesuatu. Hubungan sosial yang ada termasuk aturan yang dibuat, juga harus berdasarkan pada ketentuan tersebut.

Elena Andreeva, dkk, (2017), menyebutkan bahwa modernisasi itu merupakan transisi dari tradisional menuju masyarakat modern, yang mengadaptasi faktor-faktor makro sosial. Disini akan terlihat adanya pengurangan penerapan nilai-nilai tradisional termasuk bebagai aturnannya yang secara bertahap dan sistematis menuju nilai-nilai universal dengan menggunakan pilihan-pilihan yang sifatnya rasional. Pada level lokal disebutkan bahwa ukuran yang dapat dilihat dari adanya modernisasi tersebut adalah adanya pembangunan untuk kelompok pekerja berserta potensi-potensi entrepreneur dan perbaikan manajemen tenaga kerja serta sistem sosialnya.

Rasionalitas dalam pandangan Darren Sherkat, berkaitan dengan pilihan rasional, dikatakan, learning atau belajar bukanlah sebuah proses sederhana yang memperlihatkan seseorang berhasil mengumpulkan akumulasi informasi akan tetapi sebuah fenomena sosial yang dipengaruhi oleh teman-teman, keluarga, komunitas dan keterikatan-keterikatan emosional lainnya (Mellor,2000). Sedangkan Ichard (2017) mengatakan bahwa yang dimaksudkan dengan rasional itu adalah dimana masyarakat menggunakan berbagai pertimbangan-pertimbangan yang sudah dilakukan dalam membuat pilihan atau keputusannya.

Elamadurthi (2012) menyebutkan bahwa nilai-nilai universal itu adalah cinta, kebenaran.perdamaian, berperilaku dengan benar dan tanpa kekerasan. Dalam berperilaku dengan baik, disebutkan mempunyai tujuan untuk memberikan kepercayaan diri pada sesorang berdasarkan inisiatif yang muncul. Sedangkan nonkekrasan artinya tidak melakukan kekarasan baik dalam bentuk kata-kata, tindakan, dan perbuatan. Non kekerasan juga termasuk menaruh penghormatan kepada semua mahluk hidup, lingkungan, tidak mementingkan diri sendiri, mempraktikkan kesabaran dan toleransi. Ritzer (2011:149) menambahkan tentang konsep rasionalitas formal, yang mengacu kepada aturan dan norma yang bersifat universal.

Penelitian ini menggunakan jenis kualitatif eksplanatoris. Artinya peneliti terjun langsung ke lapangan, melihat gerak dinamika desa pakraman di lokasi penelitian, mewawancara, ikut terlibat dalam dinamika sosial tersebut (Bryman, 2004: 267).

\section{PEMBAHASAN}

\section{Pembaruan yang Didukung Norma}

Bagaimanapun pembaruan atau modernisasi, tidak dapat dihindarkan oleh masyarakat Bali sekarang. Dengan perkembangan industri pariwisata yang dikembangkan, maka Bali langsung bersentuhan dengan peradaban Barat yang sangat mengandalkan modernisasi dan rasionalitas. Karena itu, masyarakat Bali haruslah bersiap menghadapi hal ini dan tidak boleh menjauhinya. Jika masyarakat Bali fanatik mempertahankan tradisi lokal tanpa membuka diri untuk memperbarui, maka benturan antara modernisasi dengan tradisi tidak akan terhindarkan. Pasti akan terjadi konflik, dan konflik itu merupakan dasar dari perpecahan dan 
kekerasan. Wujud konflik tersebut dapat muncul antar kelompok, semisal pemilik hotel dengan masyarakat lokal, bule dengan masyarakat lokal, juga masyarakat lokal dengan masyarakat lokal. Seluruh konflik tersebut sangat berbahaya tetapi yang paling berbahaya dan fatal adalah konflik antar masyarakat Bali sendiri. Yang terakhir ini sudah sering terjadi, mulai dari skala ringan sampai dengan berat. Skorsing atau pelarangan penguburan jenazah pada kuburan desa, merupakan salah satu wujudnya. Kasus yang pernah terjadi adalah demikian: ketika salah seorang warga sibuk bekerja di hotel (yang mempunyai peradaban barat-modern), dan tidak dapat secara disiplin mengikuti acara ngayah di kampung (tradisionalisme), maka desa pakraman menghukumnya dengan tidak memperbolehkan menanam jenazah orang tuanya. Ini jelas sekali bentuk konflik yang dasarnya merupakan benturan antara modernism dengan tradisionalisme yang justru merugikan masyarakat Bali sendiri.

Dengan konteks demikian, maka Perda No. 4 Tahun 2019 tentang Desa Adat tersebut, harus mampu menjiwai budaya yang sesungguhnya. Bukan sekedar melindungi tradisi Bali, tetapi justru mampu mengembangkannya menjadi nilainilai yang patuh dan adaptif terhadap modernisasi. Budaya merupakan bagian dari makna kata adat tersebut, dan kemudian secara jelas diutarakan di dalam tujuan dibentuknya Perda ini.

Pada titik itulah manfaat paling penting dari perda yang baru ini. Perda ini benar-benar mampu melindungi masyarakat Bali, bukan bahkan menjadikan masyarakat sebagai sebuah koloni yang kemudian terbagi menjadi kelompokkelompok warga yang tersandera oleh kewajiban adat yang ketat. Membentuk koloni sosial yang hanya mewajibkan koloni itu untuk melestarikan tradisi, bias membahaykan perkembangan masyarakat Bali. Akan banyak masyarakat Bali menghindari adat, memilih keluar Bali atau bahkan keluar dari agama yang dianutnya.

Konsiderans perda ini sangat mentereng. Pada bagian menimbang misalnya, ada pernyataan yang mengaitkan filosofi Tri Hita Karana dengan jiwa ajaran agama Hindu dan nilai-nilai budaya yang mempunyai peran besar dalam pembangunan masyarakat sehingga perlu diberdayakan guna mewujudkan kehidupan krama Bali yang berdaulat secara politik, berdikari secara ekonomi, dan berkepribadian dalam kebudayaan (silakan dibaca kelengkapannya pada konsideransi menimbang b.) Rentetan kata dan kalimat ini saja sudah memberikan bagaimana cita-cita besar dari perda ini yang mau tidak mau harus mengadaptasi modernisasi dan pembaruan, demi mencapai cita-cita yang hendak diwujudkan tersebut. Seperti yang sudah diutarakan diatas, kata budaya saja sudah mempunyai makna yang luas. Dan dalam hal modernisasi, budaya menemukan bentuknya pada pemberdayaan. Maka, apabila dihubungkan dengan kalimat berdaulat secara politik lalu berdikari secara ekonomi, maka menjadi sebuah keharusan bagi perda ini untuk memberikan perlindungan kepada masyarakat, karma Bali. Desa adat dikelola secara professional, menghargai hak asasi manusia, menghargai aktivitas manusia, menghargai kerja dan sudah tentu tidak membuang-buang waktu. Rasionalitas 
dengan demikian, menjadi landasan berfikir dan landasan bertindak dari desa pakraman.

Hak asasi manusia yang dicantumkan sebagai konsiderans dalam perda no 4 Tahun 2019 ini, masuk dalam hal mengingat. Artinya ada peristiwa tertentu yang terjadi pada masyarakat Hindu Bali di masa lalu yang perlu diingat. Dengan tercantumnya hak asasi manusia ini, maka ada sesuatu yang terjadi terhadap hak asasi manusia masyarakat Hindu Bali di masa lalu yang harus diperhatikan. Melihat kejadian-kejadian sejarah dan peristiwa yang ada terhadap hak asasi manusia masyarakat Hindu Bali di masa lalu, maka konsiderans ini menginginkan mengakhiri atau menghilangkan kejadian-kejadian buruk di masaa lalu yang menimpa masyarakat Hindu Bali. Beberapa hal itu misalanya seperti kesepekang, pelarangan penguburan, merendahkan martabat perempuan, bahkan juga merendahkan pernikahan, warisan, konflik antar wilayah desa adat, pengrusakan jenazah, dan sebagainya. Pencantuman konsiderans ini ditujukan untuk menghindari konflik dan perendahan martabat manusia yang terkait dengan apa yang disebutkan diatas itu, dan manusia dengan masyarakatnya dapat ditata dengan cara yang lebih baik.

Perkembangan ekonomi yang pesat di Bali yang didorong oleh pertumbuhan pariwisata, telah membuat kesibukan orang Bali meningkat. Maka, tradisi pertaniaa yang ada tergantikan oleh budaya ekonomi. Tradisi pertanian yang mempunyai ciri stagnan, sangat tergantung dari alam, bergeser menuju dinamika yang dapat ditentukan sendiri oleh manusia. Masyarakat tidak menunggu alam untuk bergerak, tidak menunggu musim, tetapi tergantung atas dinamika pemikiran manausia. Hotel dengan berbagai latarnya adalah wilayah yang sangat tergantu oleh dinamika berfikir manusia. Semakin cepat manusia berfikir dan mempunyai kapasitas untuk selalu melakukan pembaruan, maka kecepatan geraknya tergantung dari kemampuan melakukan pembaruan tersebut.

\section{Hak Asasi Manusia}

Persoalan hak asasi manusia juga tidak boleh ditinggalkan manakala harus berhadapan dengan kasta di Bali. Dalam hubungan kemanusiaan yang mempunyai agama dengan Tuhan yang disembah, seharusnya tidak boleh ada kasta. Tetapi dalam kehudupan sosial manusia kasta hanya berhubungan dengan pencapaian yang dapat diterjemahkan dalam bahasa sosiologi, yaitu struktur sosial. Artinya secara ekonomi mereka orang kaya dan miskin, dan dalam hal jabatan ia pegawai rendahan dan pegawai tinggi. Tetapi sekali lagi, manusia yang lahir sama, tidak boleh ada kasta. Maka, dalam konteks ini, kasta itu benar dimengerti sebagai warna sehingga kalau diterjemahkan ke dalam bahasa ekonomi, warna ini akan menjadi etos professional. Jadi, warna adalah etos professional paling tua di dunia. Mereka yang brahmana, haruslah secara professional menjadi pendeta yang mampu menerjemahkan bagaimana ayat suci kitab suci tersebut kepada manusia. Mereka yang menjadi ksatriya haruslah menjadi pasukan pembela negara yang profesional sehingga apapun senjata yang dipakai lawan akan dapat dideteksi. Mereka yang berjualan sebagai pedagang, harus menjadi pedagang yang lihai berbisnis sehingga 
dapat mengatasi persoalan perdagangan di seluruh dunia. Dan mereka yang menjadi petami sehiarusnya menjadi petani yang paling hebat sehingga menghasilkan produk-produk yang melimpah.

Tetapi penafsiran kasta yang keliru pada masyarakat Bali, justru melahirkan kecelakaan dan perendahaan kemanusiaan di Bali. Seorang gadis yang berkasta brahmana jika menikah dengan pria yang berkasta sudra, akan direndahkan dan dibuang oleh keluarganya. Disini, pembuangan itu justru dilakukan oleh keluarganya sendiri. Dari sisi kemanusiaan, bukan saja ini melanggar hak asasi manusia, tetapi keluarga bersangkutan durhaka kepada anak wanita yang menikah dengan pria berkasta sudra tersebut. Tidak berperikemanusiaan karena pernikahan itu adalah saat yang paling kritis dalam hidup manusia karena harus ada penyesuaian antara sifat pria dan wanita dan penyesuaian tradisi dan kebiasaam yang dilakukan oleh keluarga yang baru. Maka, dalam hal perempuan yang menikah dan kemudian dibuang oleh sanak saudaranya, sangatlah menderita. Sebagai perempuan, secara fisik ia lemah dan dalam hal jiwa juga halus. Pada masa penyesuaian inilah sang perempuan harus dilindungi. Jadi, justru dilindungi, bukan dibuang semata-mata karena pernikahan dengan orang sudra. Bahwa dalam pernikahan itu ada yang disebut bulan madu, itulah masa-masa negosiasi yang masih dapat dilakukan antara laki-laki dan perempuan, dan mulai menipis pada waktu-waktu selanjutnya.

Di masa lalu, masyarakat Bali mempunyai budaya "ngarap". Artinya mengganggu jenazah, baik semasih ada di dalam wadah atau bade, maupun ketika sudah diturunkan dari wadah tersebut. Bentuk ngarap itu bermacam-macam, seperti menganggu jalannya wadah menuju kuburan, menurunkan jenazah secar kasar, bahkan ada sampai menyelupkannya ke air comberan, sampai dengan tidak ada yang mau menyentuh jenazah. Ini sangat dikaitkan dengan perilaku mereka pada saat masih hdiup.

Dengan demikian, pencantuman hak asasi manusia ini haruslah menjadi patokan berfikir dari pelaksanaan Perda No 4 Tahun 2019. Ini merupakan kemajuan dan pembaruan dari pemerintah daerah Bali terhadap upaya perlindungan kepada masyarakat. Tidak mudah untuk melaksanakan ini. Sebab, dalam perjalanannya nanti, perda ini akan ditindaklanjuti dalam pembuatan atau revisi awig-awig desa, atau kemudian memberikan masukan pada pelaksanaan pembuatan perarem. Pada titik perarem inilah nanti terlihat bagaimana pelaksanaan hak asasi manusia tersebut pada desa adat, lokus aktivitas masyarakat Hindu di Bali.

\section{Perekonomian Rakyat}

Hal lain yang terlihat urgen dalam Perda No.4 Tahun 2019 ini adalah tentang pembentukan lembaga ekonomi mikro. Tidak bisa lain, hal ini pasti mempunyai tujuan dan arah yang tertuju kepada Lembaga Perkreditan Desa (LPD). Lembaga ini pernah kontroversial di masa lalu karena LPD dinilai bertentangan dengan undang-undang yang berlaku di Indonesia. Karena itu, dicantumkannya lembaga ekonomi mikro ini dalam konsiderans, memperlihatkan bahwa pembuat 
peraturan ini, pemerintah dan legislatiF Bali, memang serius untuk urusan keuangan bagi masyarakat pedesaan. Secara sosiologis hal ini memang penting.

Dari sisi pengalaman sejarah, masyarakat di pedesaan Bali, yaitu yang melingkup desa adat atau desa pakraman, tidak pernah tersentuh oleh pembelajaran bisnis. Secara tradisional, mereka didasari oleh barter dan kemudian diperkenalkan dengan nilai tukar uang. Tetapi belum pernah mengalami terobosan-terobosan cara memanfaatkan nilai pertukaran uang seperti yang terjadi sekarang ini. Bahasa ngurupin, ngajakan masih terdengar pada kosa kata masyarakat Bali yang maknanya adalah sebuah pertukaran, baik benda maupun jasa. Pada bahasa ngurupan, misalnya barang akan ditukar dengan barang yang sama dengan barter di masa lalu. Tidak ada pertukaran uang disini. Pada kosa kata ngajakan, yang ada adalah pertukaran jasa, dimana seseorang akan meminta bantuan kepada orang lain (biasanya berkelompok) untuk mengerjakan sesuatu (misalnya menanam padi). Disini yang ada adalah pertukaran jasa, yang akan dikembalikan di masa yang akan datang, meskipun dalam ngajakan ini tetap yang mengundang itu membayarnya dengan makanan dan minuman. Mungkin juga akan diberikan barang di akhir pekerjaannya. Maka dengan kosa kata itu saja sudah dapat dikatakan bahwa secara tradisional, nilai-nilai pertukaran tersebut lebih banyak ada pada jasa dan barang.

Secara tidak langsung, sisa-sisa hal tersebut masih dipraktikkan di desa, yang membuat masyarakat tidak terampil dalam upaya pinjam-meminjam uang. Karena itulah, ketika di jaman sekarang demikian banyak perbankan yang bermunculan, terutama dengan bank perkreditan rakyat yang cabang-cabangnya sampai ke pelosok, maka ada potensial masyarakat desa aka mudah ditipu dengan berbagai peminjaman-peminjaman uang tersebut. Disamping itu, masyarakat desa juga banyak yang terkena tipu oleh rentenir atau tukang kredit lainnya.

Maka, dengan adanya inisiatif untuk membentuk Lembaga Perkreditan Desa, ini merupakan cara terbaik bagi krama Bali untuk mengatasi kekurangpengalaman tentang pertukaran uang tersebut. Dari sisi lokasi, adanya lembaga perkreditan desa yang langsung menyatu dengan desa adat, akan menjadikan rakyat lebih mudah untuk mendapatkan kredit.

Lembaga perkreditan desa ini mempunyai tempat yang ideal karena lokasinya langsung menempel pada desa adat. Dengan demikian, masyarakat akan mudah mempelajari tentang perkreditan tersebut karena lokasinya langsung menyatu. Bagi pihak lembaga, ini juga menguntungkan karena tahu betul karakter dari anggota masyarakat dan kemampuan perekonomiannya sehingga lebih mudah memberikan pinjaman. Ada aturan lain yang juga akan membuat hubungan dua pihak ini lebih mudah, yaitu rasa malu. Artinya anggota masyarakat tidak akan berani berbuat macam-macam seperti menipu misalnya, karena sanksi sosial akan langsung kelihatan begitu ketahuan karma yang tidak tertib membayar cicilannya.

Dengan demikian, lembaga perekonomian mikro ini merupakan hal penting yang akan dapat memicu pertumbuhan perekonomian masyarakat pedesaan, yang dengan demikian juga akan memberikan dorongan masyarakat untuk acara 
peminjaman uang dan mendidik mereka untuk melakukan hal tersebut, tanpa harus takut terkena tipuan dari para kreditor yang tidak bertanggung-jawab.

Di Kabupaten Tabanan, Desa Pakraman Bedha membeli lahan 1,3 hektar disamping Pura Puseh. Lahan bekas persawahan ini dibeli untuk lahan parkir yang akan padat pada saat odalan. Pembelian dari lahan ini mendapatkan dana dari usaha Lembaga Perkreditan Desa yang dikelola oleh desa pakraman tersebut. LPD ini sendiri sudah merupakan pembaruan dari desa pakraman, dan sudah tercantum dalam perda. Fungsinya adalah menciptakan ketertiban dan keteraturan agar memunculkan perasaan nyaman dalam sembahyang. Manusia akan dapat dikontrol. Manusia modern memang harus dikontrol untuk menciptakan ketertiban. Perlengkapan manusia modern jamak, karena bukan saja membawa diri tetapi juga instrumen seperti mobil, sepeda motor, sepeda, termasuk juga ponsel. Di dalam lapangan yang luas itu, juga didirikan kamar mandi. Dengan kamar mandi ini para pesembahyang akan lebih dapat berkosentrasi dalam persembshyangannya. Kamar mandi ini gratis, tidak dipungut bayaran. Dalam kompleks itu juga ada tempat jualan, konpleks dagang yang menjual makanan lokal seperti tipat cantok dan rujak lokal. Para pedagang ini berjualan, baik saat odalan maupun tidak. Artinya sehari-hari mereka juga berjualan di tempat tersebut. Untuk para pedagang ini, mereka dipungut biaya (Wawancara dengan Bapak Made Wardana, Mei 2019).

Desa Pakraman Bedha juga membuat bangunan berupa wantilan yang besar. Disamping digunakan sebagai tempat untuk melaksanakan upacara bersama seperti potong gigi massal, nyambutin massal dan sejenisnya, juga dapat dipakai kepentingan lain di luar ritual keagamaan. Misalnya dapat dipakai untuk kegiatan olahraga. Saat diselenggarakannya porda Bali bulan September 2019 yang lalu, wantilan Desa Pakraman Bedha dipakai untuk pertandingan Boxer (Wawancara Pak Surata, Juni 2019).

\section{Pembaruan di Tingkat Masyarakat}

\section{Kuburan}

Pembaruan yang dapat dilihat di kaabupaten Badung adalah wujud kuburan. Paling tidak ada dua kuburan yang telah mendapatkan pembaruan di kabupaten ini, yaitu di Desa Dalung dan Kerobokan. Sebagai sebuah tempat peristirahatan terakhir bagi jazad manusia, kuburan umumnya di Bali mendapat lokasi yang jauh dari pemukiman manusia. Sebagian masyarakat Hindu Bali menyebutnya dengan tebenan, yang artinya wilayah paling akhir atau tempatnya di posisi bawah dari pemukiman umat manusia. Karena itu, kuburan sering dipersepsikan sebagai hal yang mengerikan, kotor, dan juga wilayah terkucil. Kesan mengerikan muncul karena umumnya kuburan ditumbuhi oleh pohon-pohon besar dan rindang. Pohonpohon lain juga tumbuh tanpa perawatan. Masyarakat Hindu Bali menandai kuburan sanak keluarganya dengan membiarkan perlengkapan upacara tertancap dan sarana upakara berserakan di lokasi. Jauhnya lokasi kuburan dari pemukiman juga mempengaruhi kondisi tersebut karena jarang dibersihkan. Inilah yang membuat kesan kuburan itu mengerikan. Di masa lalu, mungkin hal ini sengaja 
dikonstruksikan untuk memelihara wibawa kuburan sehingga tidak ada orang yang berani berbuat macam-macam. Masyarakat Hindu Bali dikenal sering memberikan barang-barang bekal berharga bagi kerabatnya yang meninggal sehingga menjadi incaran bagi pencuri. Dengan kuburan yang mengerikan tersebut, diharapkan tidak ada yang berani mencuri di pekuburan desa.

Kuburan juga dipersepsikan sebagai tempat kotor. Ini disebabkan karena disamping seperti yang diuraikan diatas juga sarana untuk mengangkut jenazah seperti wadah, pembuangan air pemandian jenazah dan sarana upacara di buang di kuburan. Kain, kasur, bantal tempat tidur jenazah juga dibuang di kuburan. Dengan kondisi tersebut, kuburan dipandang tempat yang kotor, dan kerena itu mesti dihindari oleh masyarakat. Ungkapan kotor juga muncul sebagai akibat dari pandangan bahwa kuburan juga tempat penyakit yang berasal dari jenazah yang meninggal karena sakit menular. Sedangkan persepsi kuburan sebagai wilayah yang terpencil, disamping lokasinya yang jauh dari pemukiman masyarakat, juga sebagai lokasi jenazah, jazad dimana roh sudah meninggalkan fisik manusia. Di masa lalu, kuburan juga dipakai sebagai tempat "pembuangan" anggota masyarakat yang dipandang bersalah, semisal mempunyai anak kembar buncing (lakiperempuan).

Dengan uraian seperti yang disebutkan diatas, kuburan justru mempunyai persepsi yang negative bagi masyarakat. Padahal, justru kuburan mempungai nilai kegunaan yang sangat penting bagi sebuah masyarakat, yaitu sebagai terminal terakhir kisah manusia karena manusia pasti akan mati yang meninggalkan jazad. Berbeda dengan kelahiran yang tercipta dan kemudian hidup berkembang, mati adalah sebuah peninggalan. Dalam hal tubuh manusia, peninggalan itu adalah jazad yang kalau dibiarkan menumpuk, akan memunculkan persoalan sosial, salah satunya adalah penyakit dan pencemaran lingkungan.

Hal inilah yang kemudian mendapatkan garis bawah dan kemudian dieksplorasikan oleh Desa Kerobokan dan Desa Dalung, dengan memperbaiki kuburan dan membuatnya sebagai lokasi yang tertata sehingga memunculkan nilainilai estetika (keindahan dan dapat dinikmati oleh indra manusia). Hampir semua cara pandang kuburan yang ada sebelumnya, dihapuskan dan diubah dengan cara pandang yang barun bahwa kuburan itu merupakan bagian integral bagi kehidupan sosial dank arena itu harus mendapatkan perhatian dan perawatan.

Di kuburan besar Desa Dalung, pembaruan yang paling terlihat adalah mempermanenkan pembasmian dengan semen. Artinya tempat pembakaran jenazah ini dibuat permanen dengan membentuknya khusus untuk pembakaran dan dibuatkan dengan susunan bata yang direkatkan dengan semen (Wawancara Bapak Wayan Murdita, Agustus 2019). Wujud tempat pembakaran ini lebih tinggi dari tanah sekitar satu meter sehingga memudahkan bagi petugas yang akan membakar jenazah. Sebelumnya, pembasmian ini atau tempat pembakaran jenazah itu dipakai gundukan tanah yang lebih tinggi. Gundukan ini telah dipakai berdekade-dekade, dan masyarakat setempat telah mendapatkan sejak semula gundukan itu sebagai 
tempat pembakaran jenazah. Ada dua tempat pembasmian yang dimodernisir dengan semen permanen. Ini dapat dikatakan sebagai modernisasi sarana.

Di kuburan Desa Kerobokan, modernisasi itu terlihat tergabung. Artinya modernisasi itu menggabungkan antara sarana infrastruktur sekaligus juga etikaestetka. Kuburan desa Kerobokan terletak di pinggir jalan yang saat ini menjadi akses penghubung utama lokasi pariwisata Kuta dengan wilayah Bali lainnya. Pada dekade delapanpuluhan dan sebelumnya, bahkan dekade sembilanpuluhan, jalan raya ini tidak seramai sekarang dan jarang dilewati warga pada malam hari. Seiring dengan perkembangan pariwisata, jalan ini dilalui oleh banyak kendaraan siang dan malam sehingga aktivitas yang dilaksanakan di kuburan itu akan terlihat sangat jelas, termasuk diantaranya pembakaran jenazah. Tidak semua orang akan tega melihat jenazah di bakar tanpa ada penutup.

Karena itulah kemudian, kuburan Desa Kerobokan ini dipagar tembok pada bagian luar dengan estetika seni pahat Bali. Tembok ini kemudian menjadi penghias pinggir kuburan yang menambah estetika dan menghalani pembakaran jenazah dari pandangan mereka yang lewat di jalan raya. Etika pembakaran jenazah menjadi terlindungi. Artinya tidak sembarang orang dapat menyaksikan karena dalam pandangan masyarakat Hindu Bali, pembakaran jenazah merupakan peristiwa sakral dan seyogyanya tidak menjadi pemandangan umum.

Di lokasi kuburan, modernisasi infrastruktur yang terlihat selain modernisasi tempat pembakaran adalah jalan, tempat pembuangan sampah, kamar mandi dan water closet, sampai dengan tempat menaruh sarana upacara. Ini terutama dilakukan di kuburan Desa Dalung. Dengan melakukan koordinasi dan kerjasama dengan pemda setempat (Pemda Badung), jalan menuju kuburan diaspal sampai batas yang paling dekat dengan tempat penurunan jenazah. Aspal yang dipakai adalah kelas satu, jenis hotmik yang sering dipakai untuk jalan raya umum. Dengan adanya jalan aspal mulus ini pengangkutan jenazah, dilakukan secara lancar dan tidak memberikan kesempatan untuk melakukan hal-hal negative. Misalnya dengan sengaja memperlambat jalan pengangkutan jenazah. Kuburan Desa Dalung juga melakukan pembaruan yang menyentuh sisi humanis, yaitu membangun kamar mandi yang permanen dan relatif bersih. Kamar mandi ini khusus dipakai bagi anggota masyarakat yang mengikuti prosesi ngaben di kuburan tersebut. Aspek humanis ini merupakan terobosan karena tidak semua kuburan mempunyai kamar mandi khusus. Dengan dibangunnya kamar mandi tersebut, anggota masyarakat akan merasa lebih nyaman dan tenang dalam menunggu prosesi ngaben.

Secara tradisional, kuburan di Bali tidak menyediakan bangunan permanen untuk pembakaran berbagai sarana sisa pengabenen. Di kuburan Desa Dalung, hal ini diperbaiki dengan membangun tempat khusus untuk membakar sarana pengabenan, seperti wadah, sisa perlengkapan upacara, termasuk juga kasur tempat pemulasan jenazah. Adanya tempat ini membuat kuburan bebas dari sisa-sisa upacara tersebut dan bersih setelah usai upacara. Disamping menyediakan tempat sarana untuk banten, bagi anggota masyarakat yang menunggu atau menyaksikan 
prosesi pengabenan sampai selesai, disediakan bangunan khusus berbentuk balai yang mampu menampung sekitar seratus orang, lengkap dengan kursinya.

Di Desa Gubug, Kecamatan Tabanan, Kabupaten Tabanan, Kuburan juga diperbaiki dan disesuaikan dengan perkembangan jaman. Kuburan ini membentang sekitar satu hektar di pinggir jalan raya Yeh Gangga-Tabanan sehingga segala aktivitas yang dilaksanakan dalam prosesi penguburan atau ngaben, pasti akan kelihatan oleh mereka yang lalu-lalang di jalan raya. Dengan bertambah ramainya lalu lintas dan diperbaikinya jalan dengan aspal jalan yang mulus, kuburan ini juga diperbaiki dengan cara menghias dan memberikan tembok pinggir. Meskipun aktivitas ritual tetap terlihat dari jalan tetapi kesan angker terhadap kuburan ini tidak lagi kelihatan (Wawancara dengan I Gusti Putu Darta, Mei 2019).

Hal yang sama juga terlihat di kuburan Desa Wongaye Gede, di daerah pegunungan di bagian utara Tabanan. Desa ini merupakan desa kuno yang mempraktikkan ritual ngaben tidak dengan membakar jenazah. Meskipun posisi kuburannya di pinggir jalan raya, tetapi lalu-lintas di daerah ini tidak terlalu padat. Akan tetapi kesadaran untuk memperbaiki kuburan dan mempercantiknya telah ada di masyarakat yang membuat kuburan juga diberikan tembok penyengker sehingga kesan dari angker dan menakutkan itu tidak ada lagi.

\section{Pengangkutan Jenazah}

Desa Adat Penyalin, merupakan desa dengan penduduk sedikit. Desa adat ini terdiri dari satu banjar adat, yaitu Banjar Adat Penyalin. Sebagai sebuah desa adat, yang sebelumya bernama desa pakraman, Penyalin merupakan desa baru karena berdiri tahun 2002 dengan jumlah kepala keluarga hanya 55 keluarga. Desa ini komplit mempunyai wilayah dengan perbatasan alam yang sudah ditetapkan sejak masa lalu. Juga telah mempunyai Pura Dalem, Desa dan Puseh sebagai persyaratan untuk menjadi desa adat. Dan yang paling penting adalah adanya kuburan yang luasnya cukup besar apabila dibandingkan dengan jumlah penduduknya. Kuburan ini juga terbagi menjadi dua bagian, yaitu bagian untuk jenazah orang dewasa dan jenazah anak-anak.

Yang paling kelihatan dalam pembaruan di desa ini adalah diijinkannya warga menggunakan mobil untuk mengangkut jenazah dalam melaksanakan pengabenan. Ini merupakan terobosan yang luar biasa karena sebelumnya tidak pernah terjadi. Terobosan ini boleh dikatakan melompati terobosan yang dilakukan di daerah lain di Bali, terutama di Depasar. Penggunaan kereta untuk mengangkut jenazah telah dilakukan di beberapa desa di Denpasar.

Penggunaan kereta jenazah menuju kuburan, kini sudah menjadi alternatif yang dipilih secara umum oleh masyarakat. Tetapi untuk wilayah pedesaan, hal ini masih belum begitu memasyarakat. Di Denpasar, fenomena memakai kereta untuk pengangkutan jenazah ini sudah umum. Hampir semua keluarga yang mempunyai anggota keluarga yang meninggal, akan memakai metode ini untuk mengangkut jenazah menuju kuburan. Di Banjar Grenceng misalnya, hampir setiap keluarga memakai metode ini untuk mengangkit jenazah menuju kuburan. Di Kabupaten 
Badung, sarana ini dipakai terutama di wilayah Badung bagian selatan dan yang mempunyai perbatasan dengan kota Denpasar. Di Kabupaten Tabanan, fenomena ini tidak terlalu umum, akan tetapi sebagian sudah melakukan hal itu untuk mempermudah mengangkutan menuju kuburan. Hal yang sama juga dijumpai di Kabupaten Gianyar. Wilayah-wilayah yang masih berada di pegunungan, masih belum menggunakan hal seperti itu.

Tetapi mengangkut jenazah dengan wadah yang menempel pada mobil, justru Desa Adat Penyalin telah melakukannya. Jadi, wadah itu ditempatkan di atas mobil, dan mobil lah yang kemudian mengangkut wadah dengan jenazahnya itu sampai di kuburan. Ada bahaya memang dalam hal ini karena apabila gagal mengontrol pegas dari kendaraan, mobil bisa melompat dan mendatangkan bahaya bagi masyarakat dan jenazah itu sendiri. Sebanyak dua kali sudah Desa Adat Penyalin menyelenggarakan upacara ngaben dengan cara seperti ini, dan tidak mendapatkan protes dari anggota masyarakat atau karma Desa Adat Penyalin (Wawancara dengan Gusti Ketut Wikertidita, Juni 2019, dan kesaksian penulis di dalam ritual itu) .

Seharusnya proses pengangkutan jenazah di desa adat Penyalin tersebut dapat menjadi contoh bagi desa-desa adat lainnya, terutama yang berhubungan jalan dengan Desa Adat Penyalin. Desa adat ini berada di perempatan sangat strategis, antara jalan poros utama Jawa-Bali (Denpasar-Gilimanuk) dan jalan menuju ke kecamatan Kerambitan serta jalan menuju desa Kutuh. Manakala berlangsung prosesi pengabenen, lewatnya wadah yang membawa jenazah tersebut, pasti di jalan utama tersebut. Tepat di perempatan wadah akan berputar dan menyetop semua kendaraan yang lewat. Apabila wadah diangkut menuju kuburan, maka akan melewati dan menyusuri jalan utama itu.

Ini artinya banyak penumpang kendaraan yang berhenti dan melihat jalannya proses pengangkutan jenazah. Manakala jenazah itu diangkut dengan wadah yang bermobil, akan menjadi tontonan dan akan mendapatkan perhatian dari para penumpang kendaraan. Dari sinilah diharapkan pemandangan yang disaksikan tersebut akan menjadi percontohan dan disebarkan oleh masyarakat yang menonton dari mobil, sehingga pembaruan tersebut dapat disebarkan menuju tempat-tempat lain.

\section{Ritual Massal}

Di Kabupaten Tabanan, Desa Pakraman Bedha yang beranggotakan 38 banjar pakraman melakukan terobosan lain yang dapat memberikann inspirasi terhadap jalannya upacara. Desa pakraman ini merupakan yang terbesar di Tabanan yang membentang pada tiga kecamatan, yaitu Kecamatan Kerambitan dan Kecamatan Tabanan. Meskipun pembaruan yang dilakukan merupakan kelanjutan dari pembaruan yang dilakukan oleh kelompok masyarakat Pasek yang ada di Peguyangan Kangin, akan tetapi mempunyai makna lain apabila dihubungkan dengan mitos terasing atau kesepekang dan mitos rumitnya upacara masyarakat Hindu Bali. Pada decade sembilanpuluhan, manakala ada pihak yang melakukan upacara potong gigi, atau tigabulanan di griya, dikatakan sebagai keluarga yang 
tidak diakui banjar. Tetapi sekarang justru Desa Pakraman Bedha telah memelopori adanya upacara ritual sederhana seperti itu, dengan membangun kompleks upacara. Mereka melaksanakan upacara ini secara rutin setiap enam bulan sekali atau tiga bulan sekali. Tahun 2020, Desa Pakraman Bedha mempunyai krematorium (wawancara dengan Ketut Wijana, Juni 2020). Dengan adanya krematorium ini maka pembakaran jenazah dapat dilakukan dengan lebih cepat dan dapat menghindari persoalan-persoalan yang ada.

Pembaruan yang dilakukan desa pakraman ini penting sebab anggota masyarakat yang menjadi anggota desa pakraman tersebut, kebanyakan berasal dari kelompok masyarakat petani yang masih mempertahankan tradisi secara kuat. Kebanyakan anggotanya juga masih beraliran konservatif, dalam arti masih mempertahankan tradisionalitas yang didapatkan dari praktik pendahulunya.

Karena itu, manakala pembaruan tersebut dilakukan oleh lembaga yang memayungi mereka, maka hal ini akan sangat membantu masyarakat anggota untuk memahami makna pembaruan tersebut, dan pembaruan yang dilakukan oleh lembaga tersebut menjadi legitimasi bagi pelaksanaan upacara. Lembaga adalah orang tua dan panutan. Dengan demikian pembaruan upacara yang dilaksanakan oleh lembaga akan diikuti oleh pembaruan upacara pada tingkat yang lebih rendah, yaitu di banjar pakraman dan keluarga. Ini sangat penting bagi masyarakat desa pakraman Bedha yang sebagian wilayahnya telah terkepung oleh pembangunan sarana industri pariwisata. Industri ini sangat mementingkan sikap professional, disiplin waktu dan tenaga. Sehingga peneyderhanaan ritual itu akan menyisakan waktu, untuk kemudian dipakai berkompetisi dalam dunia kerja pada industri pariwisata.

\section{Hambatan Pembaruan}

\section{Ketakutan Kehilangan Tradisi}

Hambatan paling kelihatan dari lambatnya pembaruan yang ada di desa pakraman adalah ketakutan atas kehilangan tradisi. Ketakutan ini bersumber pada ketidaktahuan akan makna ritual dan berkorelasi dengan kepercayaan-kepercayaan. Ketidaktahuan ini bersumber pada kurangnya berbagai terjemahan terhadap kitab suci dan sumber-sumber sastra yang dipakai rujukan. Lagi-lagi hal ini berhubungan dengan tidak banyaknya penafsir dan penerjemah dari rujukan tersebut. Semuanya itu memberikan pengaruh yang besar, yaitu kebingungan dalam menjalankan upacara dan ketidaktahuan tentang mana kitab suci dan mana yang sastra. Kitab suci Hindu Bali adalah Bhagawat Gita, kitab suci universal Hindu yang tidak dipengaruhi oleh berbagai sekte yang ada seperti halnya di India. Akumasi itulah yang membuat segala upaya pembaruan terhadap ritual Hindu Bali menjadi terhambat atau dalam bahasa yang lebih sederhana lambat sekali pembaruannya. Kata akhir yang sering dipakai untuk membela diri adalah gugun tuwon atau yang di Bali sering diungkap dengan "mule keto".

Sebagai sebuah tradisi, segala ritual yang dalaksanakan di Bali itu adalah pengulangan peristiwa yang sudah berdekade-dekade berlangsung. Bahkan itu 
sudah berlangsung berabad-abad. Tradisi ritual yang telah berlangsung erabadabad itu memang mempunyai fungsi positif, salah satunya adalah mengikat persatuan di masyarakat. Ada kepercayaan dan rasa bahwa peristiwa itu milik bersama. Apalagi kemudian tradisi itu diselipi dengan fungsi lain, misalnya untuk menyembuhkan sakit.

Di Kabupaten Tabanan, di Kecamatan Kediri ada tradisi yang disebut tektekan atau okokan yang dimaknai berfungsi sebagai penghilang grubug. Padahal ini mungkin ini awalnya sebagai tindakan yang bersumber pada ketidaktahuan penyebab wabah di daerah tersebut. Dari tradisi ini dapat saja dipandang bahwa di wilayah itu, jauh di masa lalu pernah ada wabah penyakit yang memakan korban banyak anggota masyarakat, tetapi maayarakat tidak mengetahui bagaimana harus mencegah wabah itu. Membunyikan kentongan atau okokan merupakan metode yang pada masa itu dipakai untuk menyelesaikan masalah. Wabah dipandang sebagai gangguan setan. Padahal, kalaupun kemudian wabahnya hilang, bisa jadi yang membuat itu terjadi adalah iklim yang berubah atau hujan lebat yang membuat bibit penyakitnay hilang. Diare massal akan hilang kalau di sungai kotorannya sudah hilang dihanyutkan oleh banjir. Penyebab utama inilah yang tidak diketahui di masa lalu. Masa sekarang yang sudah modern memungkinkan penemuan penyebab wabah itu sehingga tradisi dapat dikurangi atau bahkan dihentikan. Keberanian untuk mengurangi atau menghentikan tradisi inilah yang tidak ada di masyarakat, membuat temuan-temuan baru sulit tersosialisasikan.

Di Banjar Penyalin, kabupaten Tabanan ketidakpahaman atas tradisi tersebut, justru membuat masyarakat desa pakraman menjadi lebih banyak repotnya. Yang pertama adalah pembuatan atau perubahan status dari Banjar Pakraman menjadi Desa Pakraman. Sebelum menjadi desa pakraman, tempat persembahyangan yang dimiliki oleh banjar ini adalah satu tempat sembahyang, yaitu Pura Dalem. Tempat sembahyang ini merupakan manifestasi dari tempat sembahyang untuk menyembah Dewa Siwa, yang dalam konsepsi Hindu, merupakan dewa pelebur. Pura Dalem berada berdekatan dengan kuburan, seperti kebanyakan yang dipraktikkan masyarakat Hindu Bali. Pura Puseh dan Pura Desa, tidak dimiliki oleh banjar ini sehingga melakukan persembahyangan untuk dua Pura itu dilakukan di kota Tabanan. Dengan kondisi itu Banjar Penyalin masuk ke dalam Desa Pakraman Tabanan.

Di Bali, semua pemukiman sebagai tempat hidup manusia itu dibagi-bagi dalam desa pakraman. Secara religius dalam konteks kehinduan Bali, desa pakraman merupakan wilayah lingkungan hidup manusia, sebab pada wilayah inilah ada tempat persembahyangan yang komlit. Dalam kinteks kehinduan Bali, tempat sembahyang yang ada di masyarakat sekalugus yang menjadi pertanda komunitasnya adalah Khayangan Tiga. Pura Khayangan Tiga ini terdiri dari tiga tempat sembahyang sebagai manifestasi dari kekuatan Shang Hyang Widhi, yaitu Puseh, Desa dan Dalem. Pura Puseh adalah tempat untuk memuja Dewa Wisnu yang merupakan kekuatan Tuhan untuk memelihara, Pura Desa adalah untuk memuja Brahma sebsgai msnifesrasi Tuhan untuk mencipta dan Pura Dalem untuk memuja Siwa sebagai manifestasi Tuhan dalam melebur. Ini merupakan konsepsi 
Hindu Bali yang sudah berusia satu milenial, seribu rahun, yang seolah dilupakan yabg diciptakan oleh Mpu Kuturan tahun 1039 masehi. Maka, dalam pelaksanaannya ketiga Pura tersebut haruslah menyatu, boleh dalam satu kawasan dan boleh dalam persembahyangan. Konsepsi ini merupakan sebuah strategi sosial dan politis untuk menciptakan stabilitas sosial akibat banyaknua sekte di Bali pada saat

itu.

Khayangan Tiga sebagai sebuah tempat sembahyang kemudian dilundungi dan diawasi atau dalam bahasa Bali, oleh desa pakraman atau desa adat. Desa adat lah yang kemudian melaksanakan upacara yang diselenggarakan untuk Pura khayangan tiga tersebut. Secara logika, ketiga tempat sembahyang tersebut haruslah bersatu dan menyatu karena nerupakan simbolisasi manifestasi kekuatan Tuhan dalam mencipakan alam semesta dengan segala isinya. Banjar Pakraman Penyalin telah berubah status menjadi desa pakraman sejak tahun 2002. Masyarakat atas bantuan kegubernuran Bali, dapat membangun Pura Puseh dan Pura desa dalam satu kimpleks. Akan tetapi justru disinilah yang menjadi problematika dan cermin ketudaktahuan makna dan keberanian untuk melakukan terobosan.

Jika melihat dari sejarah munculnya desa pakraman dan khayangan tiga, maka pembuatan Pura Desa dan Puseh di Desa Pakraman Penyalin dapat dilakukan di tempat berdirinya Pura Dalem yang sudah ada. Hanya dengan menambahkan bangunan yang berfungsi sebagai Pura desa dan Pura Puseh, sudah dapat didirikan Khayangan Tiga. Ini tentu akan sangat memberikan kemudahan dan kemurahan sehingga dapat mengirit biaya. Akan tetapi karena tidak tahu akan adanya sejarah dan makna dari Khayangan Tiga dan hubungannya dengan desa pakraman, maka Banjar Penyalin berupaya mendaptkan tanah negara yang ada di banjar penyalin dan kemydian membangun Pura Puseh dan Pura desa dengan berbagai perlengkapannya. Biaya, waktu, tenaga dan proses administrasi dari kepengurusan tanah dan kemudian tenaga untuk menyelesaikan Pura Puseh dan desa tersebut, menjadi demikian tinggi. Pembangunan Pura ini menghabiskan dana sekitar 100 juta pada tahun 2005 dan menghabiskan waktu sekitar tiga tahun lamanya dan memerlukan berkali-kali gotong-royong dan rapat warga. Jika misalnya pembangunan itu dilakukan di tempat Pura Dalem yang sudah ada, tidak akan memerlukan proses yang demikian lama dan memerlukan banyak tenaga dan sudah pasti biaya yang dihabiskan juga tidak banyak. Semua fenomena ini disebabkan oleh tidak adanya pemahaman dan pengetahuan tentang makna upacara, tempat sembahyang, termasuk sejarah tentang berbagai tempat persembahyangan dan ritual upacara tersebut.

Berkait dengan ketidaktahuan akan sejarah dari minculnya konsep Khayangan Tiga tersebut, pada kelanjutnnya juga berpengaruh kepada perayaan odalan dari ketiga Pura tersebut. Di Desa Pakraman Penyalin, odalan yang dilakukan terhadap satu kesatuan Pura tersebut, sebanyak dua kali. Untuk Pura Dalem, karena berdiri lama sebelum didirikan Pura Puseh dan desa, odalannya dua kali dalam setahun Bali. Sedangkan untuk odalan di Pura desa dan Puseh, hanya sekali dalam setahun Bali, yaitu pada purnama ketiga. Dalam sebuah konsep dan simbolis Ketuhanan, ini adalah keliru. 
Seharusnya odalan yang dilangsungkan itu bersamaan karena tiga manifestasi itu harus menyatu dan menjadi Tuhan. Hindu Bali seperti yang dikonsepkan Mpu Kuturan itu, adalah penyembah Tuhan. Tetapi yang dilakukan di Desa Pakraman Penyalin, dan juga cukup banyak desa pakraman lain, adalah persembahyangan parsial. Tidak sama dengan konsep yang dilakukan oleh Mpu Kuturan. Akibat sosialnya cukup signifikan, yaitu penghabisan waktu tenaga dan biaya ekonomi. Ini kelanjutannya membawa dampak kepada tata kerja kantoran, profesi. Masyarakat yang menjadi anggota desa pakraman itu harus meminta ijin dari kantor. Ijin berkali-kali dari kantor akan membuat kualitas kondite pasti berkurang. Salah satu akibat dari ini adalah tidak diterimanya tenaga kerja Bali di salah satu hotel. Pekerja bangunan juga harus membuang kesempatan kerja hariannya. Demikian juga pedagang. Fenomena inilah yang membuat kesempatan tersebut diambil oleh warga luar. Orang Bali justru tidak dapat bekerja di lumbung padinya sendiri.

\section{Konflik}

Di Gianyar, hambatan yang paling kelihatan adalah adanya konflik-konflik yang masih ada di masyarakat. Konflik ini berkaitan dengan sumber-sumber ekonomi sebagai akibat dari perkembangan industri pariwisata yang terjadi di daerah tersebut. Gianyar merupakan salah satu daerah tujuan pariwisata yang paling pesat di Bali. Akibatnya harga-harga tanah menjadi mahal. Di masa lalu, perbatasan antara desa pakraman tidak jelas karena rasa persaudaraan masing-masing desa adat masih kuat. Perbatasan yang dipakai adalah perbatasan alam seperti sungai, pohon, atau kuburan. Pada masa lalu, nilai tanah masih tidak terpengaruh oleh industri pariwisata. Ketika pariwisata menjadi faktor penentu dalam industri di Bali, harga tanah menjadi melonjak. Inilah yang menjadi akar dari konflik yang muncul di Gianyar.

\section{Kesimpulan}

Pembaruan yang dilakukan oleh desa pakraman atau desa adat di Bali telah ada dan itu dilakukan sesuai dengan tuntutan jaman. Faktor yang mempengaruhi dan mendukung munculnya pembaruan tersebut adalah sikap rasional masyarakat. Dimulai dengan tuntutan penggunaan waktu yang efisien. Perkembangan ekonomi masyarakat Bali sekarang sudah demikian maju apabila dibandingkan dengan masa lalu, dimana budaya pertanian digantikan oleh budaya industri. Sikap rasional inilah yang memunculkan dan mendorong munculnya lembaga perkreditan desa, memunculkan ngaben di krematorium, membawa jenazah dengan kerata atau dengan mengangkut wadah dengan mobil, serta ritual yang dilakukan secara bersama-sama. Semuanya bertujuan untuk mengefisienkan waktu, memanfaatkan modal ekonomi dengan baik dan menyimpan tenaga untuk kepentingan lain. Rasionalisasi itu juga memberikan inspirasi kepada desa pakraman untuk menyewakan tanah yang dimiliki untuk kepentingan bisnis atau kepentingan sosial lain. Disamping itu juga didukung oleh adanya norma-norma baru yang mendorong masyarakat untuk bersikap rasional. Peraturan Daerah No. 4 Tahun 2019 tentang Desa Adat juga ikut memberikan dorongan untuk melakukan pembaruan tersebut. 
Dalam Perda ini, pembaruan yang diungkapkan adalah tentang hak asasi manusia serta perekonomian rakyat.

Sedangkan hambatan-hambatan yang muncul untuk pembaruan desa pakraman itu adalah adanya sikap yang tradisional. Ini merupakan paradoks dari pembaruan yang dilakukan oleh desa pakraman. Sikap tradisional ini muncul berdasar atas kekhawatiran atas kehilangan tradisi yang sudah berlangsung dari tahun-ketahun. Hal ini sebenarnya berkaitan dengan ketidakmampuan untuk belajar dan menafsirkan berbagai tradisi yang ada sebelumnya. Disamping itu, konflik juga masih menjadi salah satu penyebab pembaruan itu terhambat. Konflik ini disebabkan oleh hadirnya pengaruh pariwisata sampai ke pedesaan. Konflik inilah yang kemudian membuat perhatian dan usaha untuk memperbarui tradisi itu terhambat.

\section{Daftar Pustaka}

Andreeva, Elena dkk, 2017, "Economic and Social Impack of Modernization on Cultural Modernization, dalam Journal of International Studies, vol 10, N0. 1, 2017, h.205-206)

Bryman, Alan, 2004, Social Research Methods, Great Britain, Oxford University Press

Elamadurthi, Ranjit Kumar, 2012, "Peace Education: Universal Human Values, dalam International Journal of Multidisciplinary Educational Research, Vol 1 (3) Agustus 2012, h. 249

Galland, Olivier, dkk, 2008, "Tradition vs. Modrnity: The Continuing Dichotomy of Values in European Society, dalam Revue Francaise de Sociologie 49(5): 153, Januari 2008 h. 169)

Ichard, Thomas F, 2017, "Bayes, Bounds and Rational Analysis, h. 5, . https://stanford.edu/ icard/BBRA.pdf 9 Februari 2019, 14.10.

Ritzer, George, Nurhadi (Pen.), 2011, Teori Sosiologi: Dari Teori Klasik sampai Perkembangan Mutakhir Teori Sosial Postmodern, Bantul, Kreasi Wacana

Mellor, Philip A, 2000, "Rational Choice or Sacred Conatagion? 'Rationality', 'Non- rationality' and Religion dalam Social Compass, 47 (2).

Suka Arjawa, I Gusti Putu Bagus, 2017, "DemocraticValues in Balinese traditional society: Analysis of the making and the content of Desa Pakraman" awigawig, dalam Masyarakat Kebudayaan dan Politik Vol 30 (4), OctoberDecember 2017, h. 428-336

Suka Arjawa, GPB, 2015, Memaksimalkan Sumber Daya Desa untuk Memajukan Pembangunan Nasional, Tabanan, Pustaka Ekspresi,

Suka Arjawa, GPB, 2016, Ngaben di Krematorium: Fenomena Perubahan Sosial di Bali, Tabanan, Pustaka Ekspresi.

Warren Carrol, 1993, Adat and Dinas: Balinese Communities in The Indonesian State, Oxford University Press. 
Wiryawan, Gde, dkk, 2015, "Hukum adat Bali ditengah Modernisasi Pembangunan dan Arus Budaya Global", dalam Jurnal Bhakti saraswati, Unmas, Vol 4, No 2, 2015, h. 177.

Windya, I Wayan P., 2017, Desa Adat di Bali Sesudah Berlakunya UU. Tentang Desa, Makalah seminar Prodi S2 Hukum Univ Udayana bekerjasama dengan Univ. Palangkaraya, 16 Maret 2017 di Pascara Sarjana Universitas Udayana

\section{Hasil penelitian}

Sirta, 2016, Desa Pakraman, Penelitian Mandiri, Fakultas Hukum Universitas Udayana

\section{Media}

Tribun Bali.com, 17 April 2018,

Nusa Bali.com, 17 April 2018,

Theeast.co.id 13 Juni 2018

\section{Undang Undang}

Perda Provinsi Bali No 3 tahun 2001, tentang Desa Pakraman

Perda Provinsi Bali No. 4 Tahun 2019 tentang Desa Adat

Undang-Undang No.13 Tahun 2003, tentang Ketenagakerjaan

\section{Wawancara}

Bapak I Wayan Surata, Bendesa Desa Pakraman Bedha

Bapak Made Wardana (nama samaran), Pedagang di areal Desa Pakraman Bedha

I Gusti Putu Darta, Warga Banjar Gubug, Desa Pakraman Bedha

I Gusti Ketut Wikertidita, Bendesa Desa Pakraman Penyalin

I Wayan Murdita (nama samaran), Pemangku dan pelopor pembaruan kuburan Dalung.

I Ketut Wijana, Pegawai Unud yang berasal dari desa yang dekat dengan krematorium Bedha 


\section{LAMPIRAN}

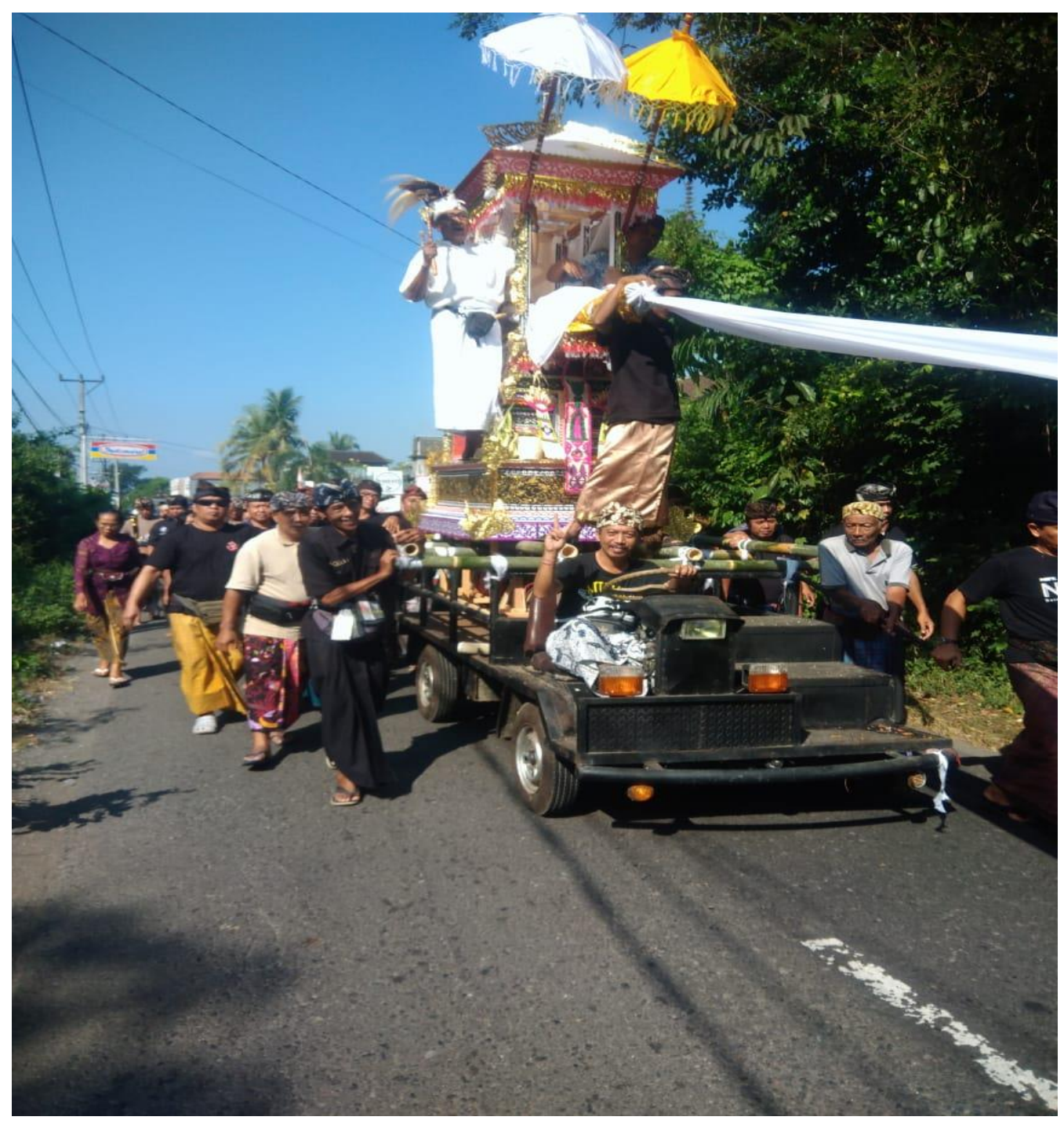

Foto perngangkutan jenazah dengan menggunakan kendaraan bermotor (mobil) sebagai tenaga utama di Desa Pakraman Penyalin. Wadah atau bade diangkut dengan mobil, dan warga hanya mengantar mobil tersebut. (Sumber: dokumen pribadi) 


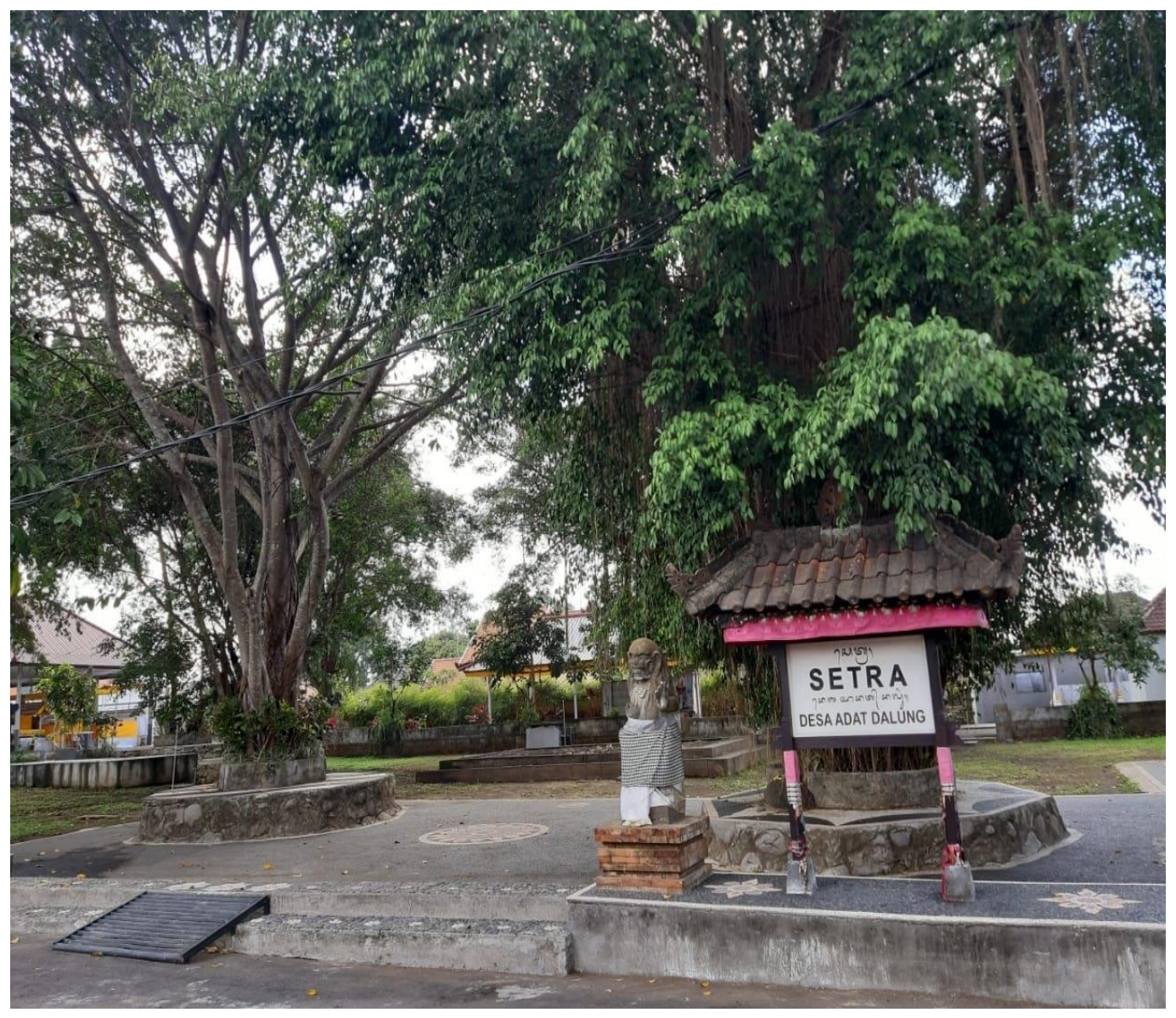

Foto kuburan Desa Adat Dalung yang tertata rapi, dengan satu tempat pembakaran untuk berbagai golongan. Pohon ditata dengan rapi dengan pelataran di semen. Jalan menuju kuburan juga diaspal dengan aspal hotmix. (Sumber: Dokumen pribadi). 